\title{
Supraventricular tachycardia due to blunt chest trauma in an adolescent
}

\author{
Hayrullah Alp, M.D., Tamer Baysal, M.D., Sevim Karaarslan, M.D.
}

Department of Pediatric Cardiology, Necmettin Erbakan University Meram Faculty of Medicine, Konya

\begin{abstract}
Blunt chest trauma and its associated complications represent a rare cause of cardiac arrest in a healthy child, although an increasing number of these events have been reported.Victims are most often diagnosed in ventricular fibrillation or tachycardia. However, cardiac conduction abnormalities are also reported. In this report, a healthy adolescent with supraventricular tachycardia associated with blunt chest trauma due to a football is presented.This is the first report in the literature of atrial arrhythmia in these cases with chest trauma.
\end{abstract}

Key words: Arrhythmia; blunt chest trauma; children; commotio cordis; supraventricular tachycardia.

\section{INTRODUCTION}

Blunt cardiac injury is more prevalent in children, ${ }^{[1]}$ and this may cause commotio cordis or ventricular arrhythmias. ${ }^{[2]}$ Commotio cordis is the devastating consequence of otherwise innocent-appearing chest-wall blows, with sudden cardiac death often resulting from projectiles striking the precordium. $^{[3]}$ This predominantly affects young male individuals, and the mean age is 14 years, with $78 \%$ under 18 years of age. ${ }^{[4]}$ Among children, the impact object is an implement of the game, a relatively hard object such as a baseball, hockey puck or lacrosse ball. ${ }^{[4]}$ The spectrum of injuries to the heart includes damage to the great vessels, myocardial rupture or contusion, and valvular disruption. ${ }^{[5]}$ Pericardial effusions, conduction abnormalities ${ }^{[6]}$ and ventricular arrhythmias $^{[7-9]}$ may also occur. However, to our knowledge, atrial arrhythmia has not been reported in the literature until now. A recent report demonstrated that blunt chest trauma due to a football caused supraventricular tachycardia in a healthy adolescent.

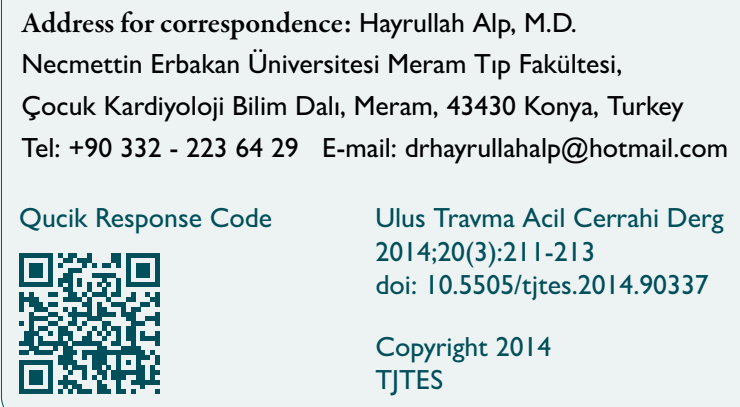

\section{CASE REPORT}

A 12-year-old school girl, previously well, was referred to our pediatric emergency department due to chest pain and tachycardia. On her initial history, it was revealed that while playing football in the school courtyard, the football hit her upper anterior chest directly, throwing her to the ground and rendering her unresponsive. After this projectile hit, she experienced tachycardia and chest pain.

She was born at term from a nonconsanguineous marriage and had had no chronic illness since birth. Her fetal and perinatal history was unremarkable. On the initial physical examination, vital signs showed a heart rate of $250 \mathrm{bpm}$ and blood pressure of I I5/75 $\mathrm{mmHg}$. The patient was awake and crying intermittently with no significant increase in blood pressure. She had no hematoma on her sternum or rib fracture. The other examination findings were all normal. Laboratory findings included creatine phosphokinase-MB $0.3 \mathrm{ng} / \mathrm{ml}$ (normal: 0-3 ng/ml) and troponin 0.1 ng/ml (normal: 0-0.4 ng/ml). An electrocardiogram demonstrated a normal QRS axis and supraventricular tachycardia with a heart rate of $250 \mathrm{bpm}$ (Fig. I). Transthoracic echocardiography and telecardiography were all normal. She was given intravenous adenosine initially at a dose of $100 \mu \mathrm{g} / \mathrm{kg}$. The sinus rhythm restored after the adenosine administration (Fig. 2). During the hospitalization, Holter monitoring did not reveal any arrhythmias besides the rare premature atrial beats. Over the next few months of the follow-up period, the electrocardiograms were normal.

\section{DISCUSSION}

Commotio cordis (disturbance of the heart) is a descriptive 


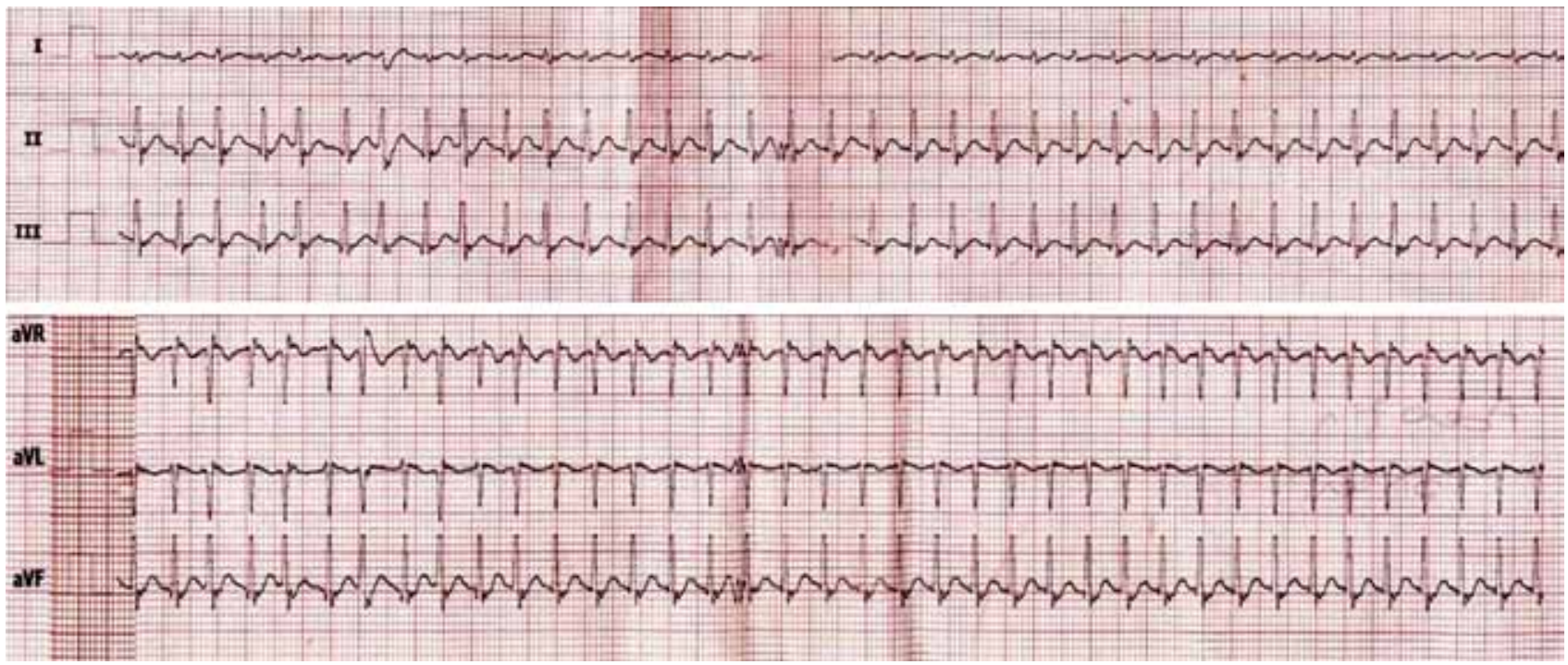

Figure 1. The electrocardiogram showing supraventricular tachycardia with a heart rate of 250/bpm.

term meaning cardiac arrest associated with low-impact blunt trauma to the anterior chest, usually by a relatively low-velocity missile, such as a baseball, cricket ball or hockey puck, or by a blow delivered by a fist, foot, elbow, or knee during sporting activities. It is not associated with any structural damage to the ribs, sternum or heart, which is otherwise known as contusio cordis. It is usually associated with sudden death in children. ${ }^{[10]}$ However, arrhythmias may also be observed in these patients instead of commotio cordis. ${ }^{[6,7,10]}$ Conduction abnormalities ${ }^{[6]}$ and ventricular arrhythmias ${ }^{[7-9]}$ such as ventricular tachycardia and fibrillation have been reported due to chest traumas. For an arrhythmia otherwise considered idiopathic, it is also novel in its clear association with a triggering factor, that is, blunt thoracic trauma. In these arrhythmias, the mechanism of onset of ventricular fibrillation from a blow to the chest is well known. In an animal model, a blow falling during the vulnerable period before the T-wave peak results in a rapid rise in left ventricular pres- sure with likely activation of ion channels via mechanoelectric coupling, leading to premature ventricular depolarization and ventricular fibrillation. ${ }^{[3]}$ Similarly, we can suggest as a mechanism that after the direct blow to the upper anterior region of the chest, a rapid rise in atrial pressure may have activated the ion channels via mechanoelectric coupling, leading to premature atrial depolarization and supraventricular tachycardia.

In commotio cordis victims, the chest blows usually strike the left chest. Most of these blows reportedly occur directly over the cardiac silhouette; however, the exact location of the chest wall strike cannot always be determined with precision. ${ }^{[10]}$ The spectrum of injuries to the heart includes damage to the great vessels, myocardial rupture or contusion, hemopericardium, poor contractility, and valvular disruption. ${ }^{[5]}$ Today, chest barriers are commonly used to protect children from the chest blows. However, in a study of Maron et al., ${ }^{[4]}$ commercially available chest wall protection was worn by
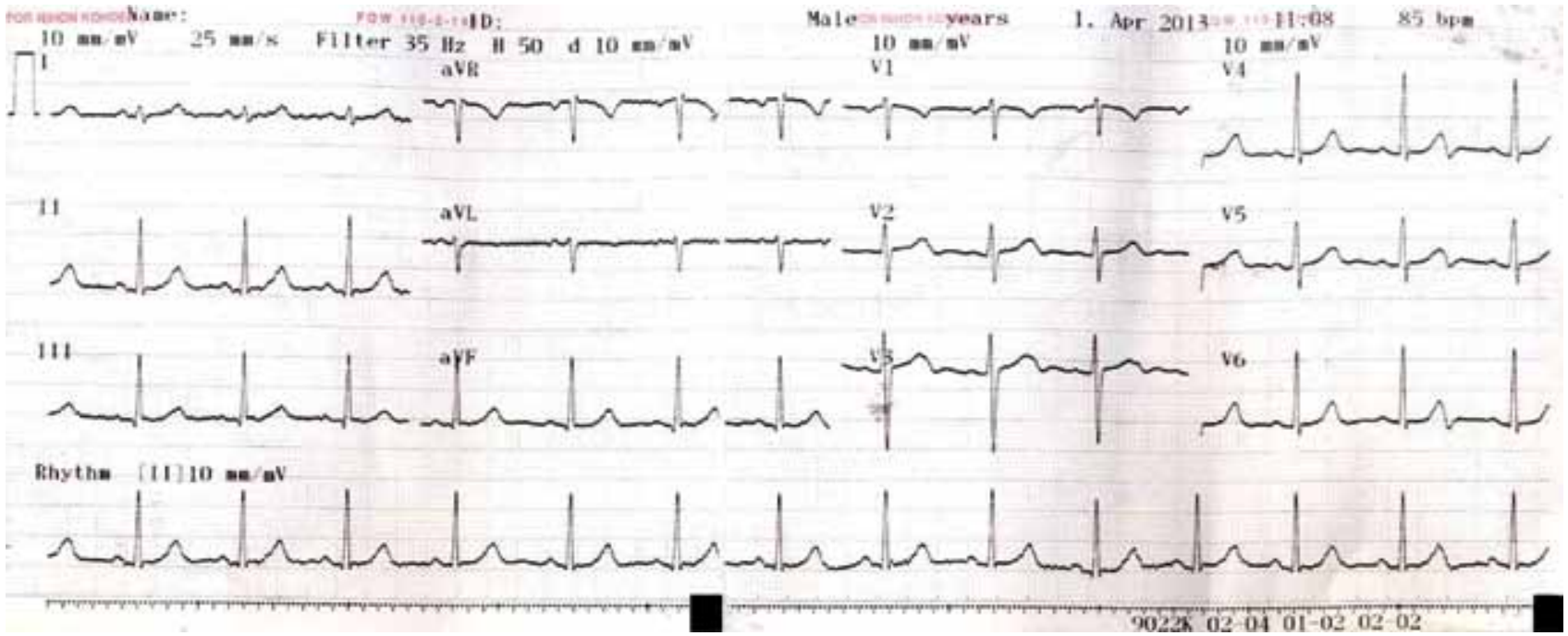

Figure 2. The 12-lead electrocardiogram showing normal axis and sinus rhythm after adenosine administration. 
22 of $79(28 \%)$ of the commotio cordis victims in organized sports, and in 13 of these individuals, the chest wall barriers did not adequately cover the left chest wall and precordium. Further, these protectors are usually used for the sports such as hockey and baseball, but not for daily sports such as football and basketball. Thus, it can be suggested that commercially available chest barriers are not sufficiently effective in preventing chest-blow-induced sudden cardiac death and, in fact, probably offer only a false sense of security to athletes, families and the general public. ${ }^{[8]}$

The treatment of supraventricular tachycardia consists of short-term or as-needed pharmacotherapy using calcium channel or beta blockers when adenosine and vagal maneuvers fail to halt or slow the rhythm. In those who require long-term pharmacotherapy, atrioventricular nodal blocking agents or class IC or III antiarrhythmics can be used. Catheter ablation is an option in patients with persistent or recurrent supraventricular tachycardia who are unable to tolerate longterm pharmacologic management.

In conclusion, blunt chest trauma and its associated complications such as arrhythmias and commotio cordis are among the current problems in sportive activities. Chest protectors are not sufficiently effective in organized sports. Associated ventricular arrhythmias may be fatal, but atrial arrhythmias may not be life-threatening, as described in the current patient.
Conflict of interest: None declared.

\section{REFERENCES}

1. Farin M, Moskowitz WB. Traumatic heart block as a presentation of myocardial injury in two young children. Clin Pediatr (Phila) 1996;35:47-50.

2. Tibballs J, Thiruchelvam T. A case of Commotio cordis in a young child caused by a fall. Resuscitation 2008;77:139-41.

3. Madias C, Maron BJ, Weinstock J, Estes NA 3rd, Link MS. Commotio cordis--sudden cardiac death with chest wall impact. J Cardiovasc Electrophysiol 2007;18:115-22.

4. Maron BJ, Gohman TE, Kyle SB, Estes NA 3rd, Link MS. Clinical profile and spectrum of commotio cordis. JAMA 2002;287:1142-6.

5. El-Chami MF, Nicholson W, Helmy T. Blunt cardiac trauma. J Emerg Med 2008;35:127-33.

6. Hebson C, Mahle W, Mao C, Drossner D. Complete heart block and echocardiographic abnormalities caused by pyrotechnic chest trauma. Pediatr Cardiol 2010;31:572-3.

7. Horduna I, Dubuc M, Rochon AG, Khairy P. Posttraumatic left ventricular tachycardia arising from the anterior papillary muscle in an otherwise healthy child. J Cardiovasc Electrophysiol 2011;22:714-6.

8. Link MS, Bir C, Dau N, Madias C, Estes NA 3rd, Maron BJ. Protecting our children from the consequences of chest blows on the playing field: a time for science over marketing. Pediatrics 2008;122:437-9.

9. Geddes LA, Roeder RA. Evolution of our knowledge of sudden death due to commotio cordis. Am J Emerg Med 2005;23:67-75.

10. Link MS. Mechanically induced sudden death in chest wall impact (commotio cordis). Prog Biophys Mol Biol 2003;82:175-86.

\section{OLGU SUNUMU - ÖZET}

\section{Bir adolösanda künt göğüs travmasına bağlı supraventriküler taşikardi}

\section{Dr. Hayrullah Alp, Dr. Tamer Baysal, Dr. Sevim Karaarslan}

Necmettin Erbakan Üniversitesi Meram Tıp Fakültesi, Çocuk Kardiyoloji Bilim Dalı, Konya

Künt göğüs travması ve bununla ilişkili komplikasyonlar çocukluk çağında görülen kardiyak arrestin nadir nedenleridir. Ayrıca, bu olgular da giderek artan sayıda bildirilmektedir. Kurbanlar sıklıkla ventriküler fibrilasyon veya taşikardi ile teşhis edilmektedir. Bununla birlikte kardiyak ileti bozuklukları da bildirilmektedir. Bu yazıda, futbol topu ile künt göğüs travmasına bağlı supraventriküler taşikardi gelişen sağlıklı bir adolösan olgu sunuldu. Bu olgular içerisinde göğüs travmasına bağlı atrial aritmi olması nedeniyle literatürdeki ilk bildiridir.

Anahtar sözcükler: Aritmi; çocuklar; kalp yaralanması; künt göğüs travması; supraventriküler taşikardi.

Ulus Travma Acil Cerrahi Derg 20I4;20(3):2II-2I3 doi: 10.5505/tjtes.2014.90337 